\title{
Estimation of Some Physico-Chemical Parameters of Tannery Effluents to Surrounding Environment (A Yemeni Case Study)
}

\author{
Adel A. M. Saeed ${ }^{1, *}$, Nasser M. N. Masood $^{2}$, and Ali N. A. Al-Kumi² \\ ${ }^{1}$ Department of Chemistry/Faculty of Science, University of Aden, Khormaksar, Aden, Yemen \\ Email: adel_saeed73@yahoo.com, ORCID iD: 0000-0002-1154-2994 \\ ${ }^{2}$ Department of Chemistry/Faculty of Education, University of Abyan, Lawdar, Abyan, \\ Yemen
}

\begin{abstract}
:
Water pollution caused by leather industrial effluent discharges has become a troublesome phenomenon due to its negative impact on environmental health and safety. In this paper, the wastewater in the vicinity of Lawdar tannery areas was assessed in two years from October 2019 to June 2021 to determine physico-chemical parameters of industrial effluents of Lawdar tannery at four different area points. Tannery effluents were collected and all samples were analyzed in the laboratory and rated as no freshwater with parameters such as acidity and basicity, temperature, electrical conductivity, total dissolved solids, total suspended solids, chemical oxygen demand, biological oxygen demand, color, turbidity, hardness, alkalinity, and several positive and negative ions. The investigation showed that all physico-chemical parameters were higher than the standard disposal limits of discharged water quality. The findings of this research will assist the government and tanneries in the treatment of wastewater before discharging to the environment and monitoring the dump sites with regards to disposal arrangement of the tannery effluents and environmental assessment.
\end{abstract}

Keywords: Physico-chemical parameters, Pollution analysis, Tannery effluents, Negative environmental impact, Yemeni study 
أصبح التلوث الناثنئ عن تصريف المخلفات السائلة لصناعة الجلود ظاهرة مقلقة بسبب التأثير السلبي على صحة البيئة والأمان. في هذه الورقة البحثية، تم دراسة مخلفات مياه دباغة الجلود من البيئة المحيطة بمدبغة لودر لمدة سنتين في الفترة بين أكتوبر 2019م وحتى يونيو 2020م لتقدير الخواص الفيزيوكيميائية للمخلفات السائلة لمدبغة لودر. حللت العينات في المختبر لقياس بعض المؤشرات مثل الحرارة، درجة الحموضة، التوصيلية الكهربائية، اللون، العكارة، الذائبية الكلية للمواد الصلبة، المواد المعلقة الصلبة الكلية، القساوة، القلوية، بعض الأيونات السالبة والموجبة... إلخ. اظهر الاستقصاء أن المؤشرات الفيزيوكيميائية كانت أعلى من القيم القياسية لنوعية المياه المصرفة لهذا نوصي بمعالجة هذه المخلفات المائية قبل تصريفها للبيئة المحيطة كما نوصي بمر اقبة أماكن التصريف لغرض التقييم البيئي.

الكلمات المفتاحية: المؤشرات الفيزيوكيميائية، تحليل الثلوث، المياه المخلفة من الدباغة، التأثير السلبي على البيئة، در اسة يمنية

\section{Introduction}

Industry has become an integral part of modern society and has provided comforts to human beings. On the other hand, the production of waste is inevitable of industrial activities. Those wastes may cause a probable hazard to environment and human life when improperly treated, stored, transported or disposed of, or managed (Tariq et al., 2006; Sulieman et al., 2010). Tannery waste is generated in massive quantities during the route of tanning by leather industries throughout the world. It has been considered one of the most polluted industrial wastes and contains high amounts of pollutants which are very toxic to groundwater, plants, animals, and land (Raj et al., 1996). The tannery industry consumes massive volumes of water daily and, as a result, generates a large amount of liquid effluents. The discharge of several wet sub-processes of tanneries such as pickling, bathing, dyeing, tanning, and fat liquoring may pollute the environment strictly (Subramanyam and Sambamurty,2006). The characteristics of the release effluents differ significantly from tannery to tannery depending upon the amount of the requested products and the design efficiency of the tannery, chemicals used for a specific process, amount of water used, and type of final product produced by a tannery (Tadesse et al.,2017). 
The current pattern of industrial activity alters the natural flow of materials and introduces several chemicals into the environment. The discharge of various inorganic and organic substances, toxic metallic compounds, biological oxidizable tanning materials, and large quantities of decomposing suspended matter is one of the key factors that exert negative influences on human life and the environment (Akan et al.,2007; Beg \& Ali, 2008; Salah et al.,2012). High levels of pollutants in water cause an increase in chemical oxygen demand (COD), biological oxygen demand $\left(\mathrm{BOD}_{5}\right)$, total dissolved solids (TDS), and total suspended solids (TSS) and hence make such water unsuitable for drinking, irrigation, and aquatic organism (Tariq et al.,2006; Ling et al., 2012). For environmental and health reasons, several techniques, processes, and treatments were applied to the effluent and wastewater of leather tannery to reduce or remove the contaminants (Bhaduri, 2021; Saha \& Azam 2021; Sponza,2021; Sultana et al.,2021; Whitehead et al ,2021).

The objective of the recent study was to investigate tannery effluent composition to better understand the suitable treatment performance of the process and identify physical and chemical contaminants of concern. The outcomes of this work can guide future regulatory needs that will best protect environmental and public health. We selected a tannery located within the populated city of Lawdar, Abyan governorate/Yemen as our field site, and employed conventional physico-chemical water quality analysis to check the treatment process and the effluent.

We wish that this study can be an abundant resource and offer a pathway for leather industries in Yemen and other similar countries to understand the tannery effluent hazards, to check the wastewater with available limits standards, and to get familiar with effective treatment technologies of solid and liquid wastes.

\section{Experimental Methodology}

\subsection{Location of the Study}

The samples were taken from Lawdar district (situated in south-western Yemen and located in Abyan Governorate). The coordination of the study area (Figure1) falls in $13^{\circ} 53^{\prime} 04.2^{\prime \prime} \mathrm{N}$ $45^{0} 51^{\prime} 48.9^{\prime \prime} \mathrm{E}$. 


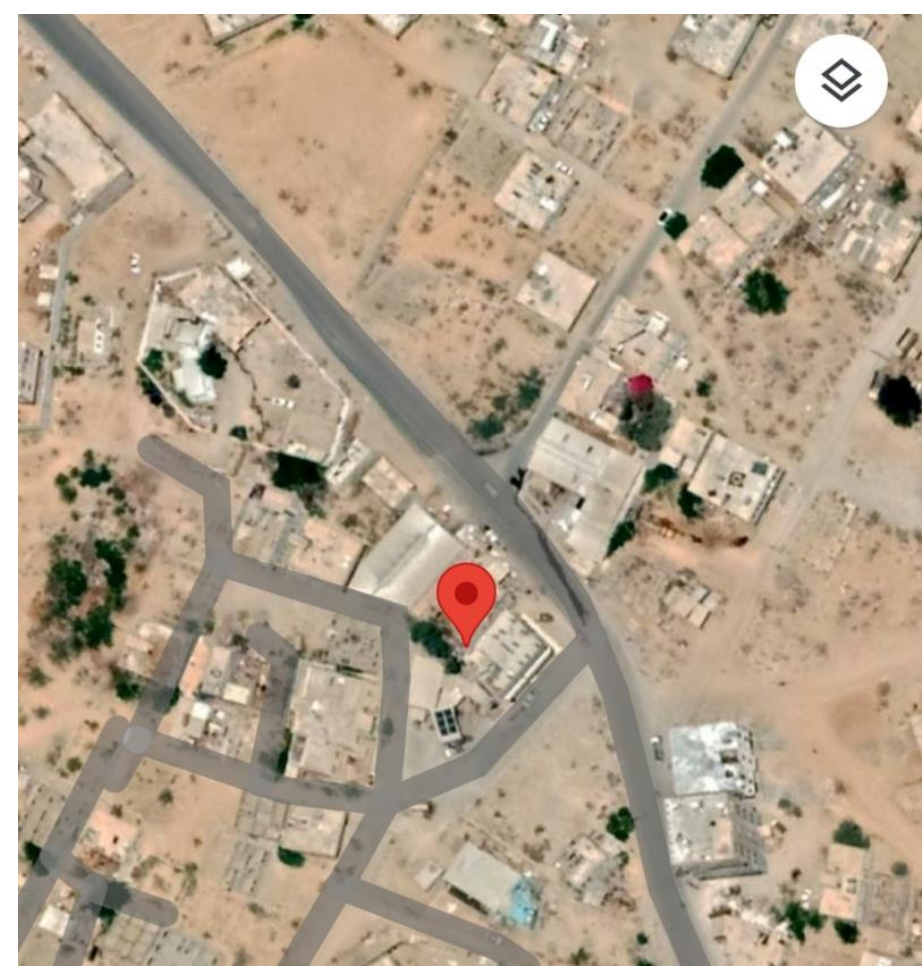

Figure1: Map showing study location.

\subsection{Sampling}

The wastewater samples of the tannery were collected during the period from October 2019 to June 2021. They were taken from a tank that was devoted for taking the wastewater from the tannery to the sewers in the area of the study. These samples were put in polythene bottles, and $100 \mathrm{ml}$ were put after filtering those samples (Jeffery,1996). The data set taken in this study is comprised of 23 parameters such as water temperature, acidity and basicity $(\mathrm{pH})$, electrical conductivity (EC), color, turbidity, total dissolved solids (TDS), total alkalinity as $\mathrm{CaCO}_{3}$ and as $\mathrm{Ca}\left(\mathrm{HCO}_{3}\right)_{2}$, total hardness as $\mathrm{CaCO}_{3}$, chemical oxygen demand (COD), biological oxygen demand ( $\left.\mathrm{BOD}_{5}\right)$, total suspended solids (TSS), dissolved ions such as calcium, magnesium, sodium, potassium, iron, manganese, nitrite, nitrate, chloride, fluoride, and sulfate ions. The temperature, $\mathrm{pH}$, and electrical conductivity were measured for 30 minutes. The other discharged water quality parameters were determined within 82 hours except for $\mathrm{BOD}_{5}$, which was determined only after 5 days of incubation at $20^{\circ} \mathrm{C}$. They were preserved in a fridge and taken to WETEX Water Systems Company -AdenYemen. The methods of analysis of water quality parameters were applied following (Jeffery, 1996; APHA, 2005) and summarized in Table (1). 
Academic Journal of Research and Scientific Publishing | Vol 3 | Issue 30

Publication Date: 5-10-2021

ISSN: 2706-6495

\begin{tabular}{|c|c|c|c|c|c|}
\hline SN & Parameters & Abbreviation & Unit & $\begin{array}{l}\text { Analytical } \\
\text { method }\end{array}$ & Instrument/Equipment \\
\hline 1 & Temperature & Temp. & ${ }^{0} \mathrm{C}$ & Electrometric & $\begin{array}{c}\text { pH meter with Temp. } \\
\text { probe }\end{array}$ \\
\hline 2 & Acidity/ basicity & $\mathrm{pH}$ & --- & Electrometric & $\begin{array}{c}\mathrm{pH} \text { meter with glass } \\
\text { electrode }\end{array}$ \\
\hline 3 & $\begin{array}{l}\text { Electrical } \\
\text { conductivity }\end{array}$ & $\mathrm{EC}$ & $\mu \mathrm{S} / \mathrm{cm}$ & Electrometric & $\begin{array}{l}\text { Conductivity meter with } \\
\text { cell probe }\end{array}$ \\
\hline 4 & Color & --- & UTC & Photometric & Photometer \\
\hline 5 & Turbidity & Turbidity & NTU & Turbidimetric & Turbidity meter \\
\hline 6 & $\begin{array}{l}\text { Total dissolved } \\
\text { solids }\end{array}$ & TDS & $\mathrm{mg} / \mathrm{L}$ & Electrometric & Conductivity/TDS meter \\
\hline 7 & $\begin{array}{l}\text { Total suspended } \\
\text { solids }\end{array}$ & TSS & $\mathrm{mg} / \mathrm{L}$ & Electrometric & Conductivity/TSS meter \\
\hline 8 & $\begin{array}{l}\text { Chemical oxygen } \\
\text { demand }\end{array}$ & COD & $\mathrm{mg} / \mathrm{L}$ & $\begin{array}{c}\text { Digestion } \\
\text { followed by } \\
\text { titration }\end{array}$ & COD digestor \\
\hline 9 & $\begin{array}{c}\text { Biochemical } \\
\text { oxygen demand }\end{array}$ & $\mathrm{BOD}_{5}$ & $\mathrm{mg} / \mathrm{L}$ & $\begin{array}{c}5 \text { days } \\
\text { incubation at } \\
20^{\circ} \mathrm{C} \text { followed } \\
\text { by titration }\end{array}$ & BOD incubator \\
\hline 10 & $\begin{array}{l}\text { Total hardness as } \\
\mathrm{CaCO}_{3}\end{array}$ & Hardness & $\mathrm{mg} / \mathrm{L}$ & Photometric & Photometer \\
\hline 11 & $\begin{array}{l}\text { Total alkalinity } \\
\text { as } \mathrm{CaCO}_{3}\end{array}$ & Alkalinity & $\mathrm{mg} / \mathrm{L}$ & Photometric & Photometer \\
\hline 12 & $\begin{array}{l}\text { Total alkalinity } \\
\qquad \mathrm{Ca}\left(\mathrm{HCO}_{3}\right)_{2}\end{array}$ & Alkalinity & $\mathrm{mg} / \mathrm{L}$ & Photometric & Photometer \\
\hline 13 & Chloride & $\mathrm{Cl}^{-}$ & $\mathrm{mg} / \mathrm{L}$ & Photometric & Photometer \\
\hline 14 & Nitrate & $\mathrm{NO}_{3}^{-}$ & $\mathrm{mg} / \mathrm{L}$ & Photometric & Photometer \\
\hline 15 & Nitrite & $\mathrm{NO}_{2}^{-}$ & $\mathrm{mg} / \mathrm{L}$ & Photometric & Photometer \\
\hline
\end{tabular}




\begin{tabular}{|c|c|c|c|c|c|}
\hline 16 & Fluoride & $\mathrm{F}^{-}$ & $\mathrm{mg} / \mathrm{L}$ & Photometric & Photometer \\
\hline 17 & Sulphate & $\mathrm{SO}^{-2}$ & $\mathrm{mg} / \mathrm{L}$ & Turbidimetric & Turbidity meter \\
\hline 18 & Sodium & $\mathrm{Na}^{+}$ & $\mathrm{mg} / \mathrm{L}$ & Photometric & Photometer \\
\hline 19 & Potassium & $\mathrm{K}^{+}$ & $\mathrm{mg} / \mathrm{L}$ & Photometric & Photometer \\
\hline 20 & Calcium & $\mathrm{Ca}^{+2}$ & $\mathrm{mg} / \mathrm{L}$ & Photometric & Photometer \\
\hline 21 & Magnesium & $\mathrm{Mg}^{+2}$ & $\mathrm{mg} / \mathrm{L}$ & Photometric & Photometer \\
\hline 22 & Iron & $\mathrm{Fe}^{+3}$ & $\mathrm{mg} / \mathrm{L}$ & Photometric & Photometer \\
\hline 23 & Manganese & $\mathrm{Mn}^{+2}$ & $\mathrm{mg} / \mathrm{L}$ & Photometric & Photometer \\
\hline
\end{tabular}

Table 1: Analytical methods and equipment used in the study

\subsection{Statistical Analysis}

Statistical analysis was performed using SPSS Statistical Package v20. Data were expressed as mean, standard deviation $( \pm \mathrm{Sd})$, standard error $( \pm \mathrm{Sr})$, lower bound-upper bound, minimum-maximum (Min-Max) values. and analysis of variance (ANOVA) was examined. The significant variation of the concentrations of the parameters in wastewater samples was tested at $\mathrm{p} \geq 0.05$ (95\% confidence level). The significant variation of the four different batches (i.e., S1, S2, S3 and S4) was analyzed to determine the mean distribution of the average concentration of the analyte along with the sampling sites and compare the arithmetic mean with the standard disposal limits (discharging inland). Then, a one-way ANOVA was adopted by assuming that there is no statistically significant difference between the sampling points and their variations which were taken from the same population (homogeneity of variance). The graphs were drawn using Origin Pro v9.6.0. A comparison between the results and the standard values were performed.

\section{Results and Discussion}

The results of the four examined samples are shown in Table (2) and Figures (2) and (3).

Table 2: Some Physico-chemical parameters of tannery effluents samples 95\% Confidence Interval for Mean 
Academic Journal of Research and Scientific Publishing | Vol 3 | Issue 30

Publication Date: 5-10-2021 ISSN: 2706-6495

\begin{tabular}{|c|c|c|c|c|c|c|c|c|}
\hline Parameter & $\mathbf{N}$ & Mean & $\begin{array}{c}\text { Std. } \\
\text { Deviation } \\
( \pm \text { Sd })\end{array}$ & $\begin{array}{l}\text { Std. } \\
\text { Error } \\
( \pm \text { Sr })\end{array}$ & $\begin{array}{l}\text { Lower } \\
\text { Bound }\end{array}$ & $\begin{array}{l}\text { Upper } \\
\text { Bound }\end{array}$ & Min & Max \\
\hline $\begin{array}{c}\text { Temperature } \\
\left({ }^{\circ} \mathbf{C}\right)\end{array}$ & 4 & 31.65 & 5.713 & 2.857 & 22.56 & 40.74 & 27.30 & 39.41 \\
\hline pH & 4 & 8.325 & 2.165 & 1.083 & 4.879 & 11.77 & 5.40 & 10.20 \\
\hline E.C $(\mu \mathrm{s} / \mathrm{cm})$ & 4 & 62725 & 5856 & 2928 & 53407 & 72042 & 56060 & 70340 \\
\hline Color (UTC) & 4 & 2000 & 163.3 & 81.65 & 1740 & 2259 & 1800 & 2200 \\
\hline $\begin{array}{c}\text { Turbidity } \\
\text { (NTU) }\end{array}$ & 4 & 1040 & 93.81 & 46.90 & 890.7 & 1189 & 980.0 & 1180 \\
\hline TDS (mg/L) & 4 & 4010 & 258.2 & 129.1 & 39689 & 40510 & 39800 & 40400 \\
\hline TSS (mg/L) & 4 & 2245 & 206.8 & 103.4 & 1916 & 2574 & 2000 & 2500 \\
\hline COD $(\mathrm{mg} / \mathrm{L})$ & 4 & 4450 & 443.5 & 221.7 & 3744 & 5156 & 4000 & 5000 \\
\hline BOD5 $_{5}(\mathrm{mg} / \mathrm{L})$ & 4 & 2425 & 543.9 & 271.9 & 1559 & 3290 & 2000 & 3200 \\
\hline $\begin{array}{c}\text { Total } \\
\text { Hardness as } \\
\mathrm{CaCO}_{3}(\mathrm{mg} / \mathrm{L})\end{array}$ & 4 & 8000 & 326.6 & 163.3 & 7480 & 8519 & 7600 & 8400 \\
\hline $\begin{array}{c}\text { Total } \\
\text { alkalinity as } \\
\mathrm{CaCO}_{3}(\mathrm{mg} / \mathrm{L})\end{array}$ & 4 & 17000 & 163.3 & 81.65 & 16740 & 17259 & 16800 & 17200 \\
\hline $\begin{array}{c}\text { Total } \\
\text { alkalinity as } \\
\mathrm{Ca}\left(\mathrm{HCO}_{3}\right)_{2} \\
(\mathrm{mg} / \mathrm{L})\end{array}$ & 4 & 20585 & 299.9 & 149.9 & 20107 & 21062 & 20160 & 20840 \\
\hline $\begin{array}{c}\text { Chlorides } \\
\text { (mg/L) }\end{array}$ & 4 & 19630 & 124.9 & 62.45 & 19431 & 19828 & 19500 & 19800 \\
\hline Nitrate(mg/L) & 4 & 18000 & 163.3 & 81.65 & 17740 & 18259 & 17800 & 18200 \\
\hline Nitrite (mg/L) & 4 & 100.0 & 16.33 & 8.165 & 74.01 & 125.9 & 80.00 & 120.0 \\
\hline $\begin{array}{c}\text { Sulphates } \\
(\mathrm{mg} / \mathrm{L})\end{array}$ & 4 & 4368 & 532.4 & 266.2 & 3521 & 5215 & 3800 & 5074 \\
\hline
\end{tabular}


Academic Journal of Research and Scientific Publishing | Vol 3 | Issue 30

Publication Date: 5-10-2021 ISSN: 2706-6495

\begin{tabular}{|c|c|c|c|c|c|c|c|c|}
\hline $\begin{array}{c}\text { Fluorides } \\
\text { (mg/L) }\end{array}$ & 4 & 20.00 & 1.633 & 0.816 & 17.40 & 22.59 & 18.00 & 22.00 \\
\hline $\begin{array}{c}\text { Sodium } \\
\text { (mg/L) }\end{array}$ & 4 & 18900 & 286.1 & 143.1 & 18444 & 19355 & 18500 & 19180 \\
\hline $\begin{array}{c}\text { Potassium } \\
\text { (mg/L) }\end{array}$ & 4 & 380.0 & 16.33 & 8.165 & 354.0 & 405.9 & 360.0 & 400.0 \\
\hline $\begin{array}{c}\text { Magnesium } \\
\text { (mg/L) }\end{array}$ & 4 & 1455 & 111.2 & 55.60 & 1278 & 1631 & 1380 & 1620 \\
\hline $\begin{array}{c}\text { Calcium } \\
\text { (mg/L) }\end{array}$ & 4 & 880.0 & 16.33 & 8.164 & 854.0 & 905.9 & 860.0 & 900.0 \\
\hline Iron (mg/L) & 4 & 2.075 & 0.299 & 0.149 & 1.599 & 2.550 & 1.80 & 2.50 \\
\hline Manganese & 4 & 2.000 & 0.163 & 0.082 & 1.740 & 2.259 & 1.80 & 2.20 \\
\hline (mg/L) & & & & & & & & \\
\hline
\end{tabular}
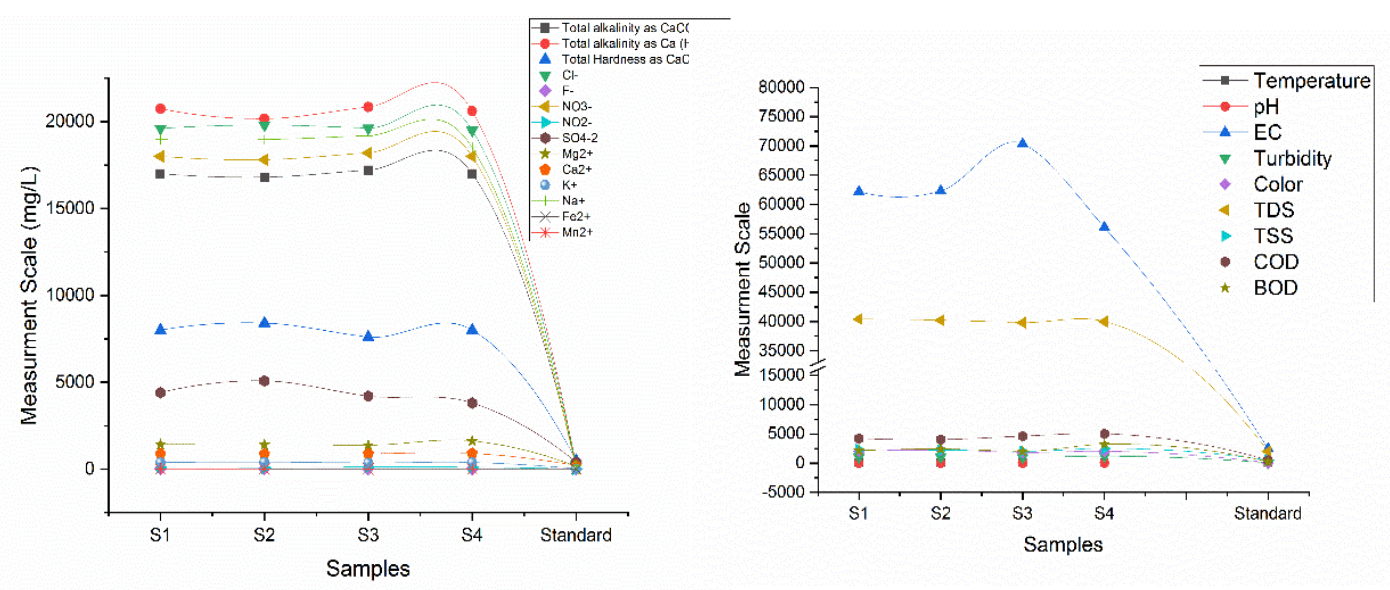

Figure 2: Concentrations of physico-chemical parameters in tannery wastewater effluent at different sampling points. Note: Separation parameters in two graphs was made for better visibility. 

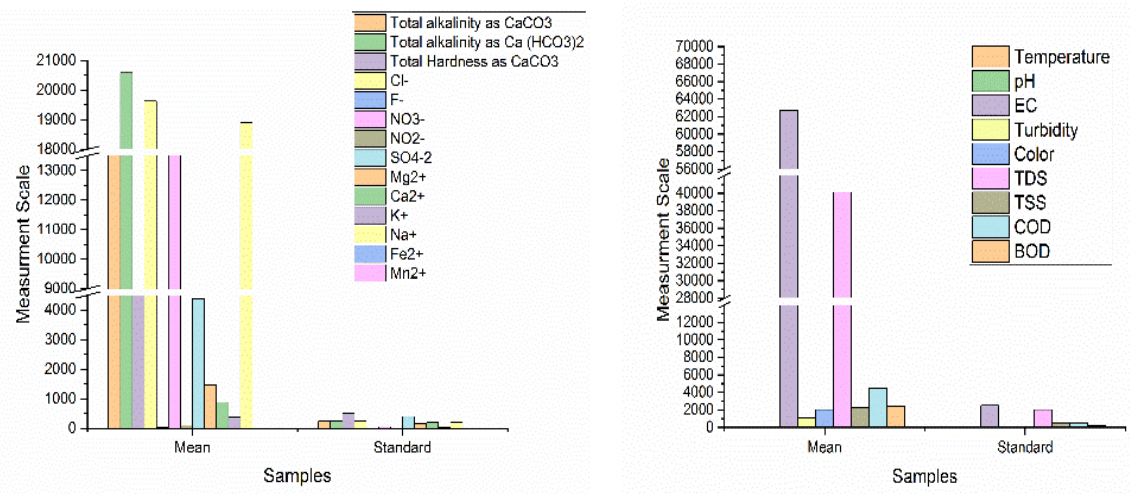

Figure 3: Mean concentrations comparison between physico-chemical parameters results and standard values in tannery wastewater effluent.

\section{Temperature, $\mathrm{pH}$, and EC}

The temperature of leather tannery effluents was taken directly after drainage within the range $\left(27.30-39.41^{\circ} \mathrm{C}\right)$ and an average of $\left(31.65^{\circ} \mathrm{C}\right)$ fits well the permissible limits $(20$ $35^{0} \mathrm{C}$ ) of ( NE, 1999). The results were ambient and almost equal to that of room temperature $\left(30^{0} \mathrm{C} \pm 2{ }^{0} \mathrm{C}\right.$ ) when observed on the day of sample collection. Thus, the effluent was not thermally polluted.

Acidity and basicity of the effluent at several sample points ranged from 5.40 to 10.2 with the mean 8.32 slightly basic on pH scale. This was within the prescribed standard limits (68.5) (NE,1999; WQR,2006). The lowest $\mathrm{pH}$ value (i.e. 5.40) may be due to addition of sulphuric acid during the pickling stage. In contrast, the highest $\mathrm{pH}$ value (10.2) may be to the use of an excessive amount of lime and sodium sulfide in leather tannery processes. The electrical conductivity of the effluent ranged from 56060 to $70340 \mu \mathrm{s} / \mathrm{cm}$ and the average electrical conductance was $(62725 \mu \mathrm{s} / \mathrm{cm})$ which was very much above the permissible limit (ISI, 2000; NEQS,2000; Hasan et al.,2021). Electrical conductivity is an excellent indicator of ionic forms of dissolved salts which can affect the taste (Solaimali \& Saravana Kumar, 2004; WHO,2017). The tolerance limit of EC is $2500 \mu \mathrm{s} / \mathrm{cm}$ as suggested by (Tariq et al.,2006). 


\section{Color and Turbidity}

The average color range of the composite tannery effluents was found to be $2000 \mathrm{Pt}-\mathrm{Co}$ units (2000 UTC) showing an orange color. This was about seven times higher than the maximum permissible limits (NE,1999).

The value of turbidity ranged from 980 to 1180 NTU with an average of (1040 NTU) greatly above the prescribed limit (NE1999; Owusu-Ansah et al, 2015). The high turbidity may increase effluent temperature due to particles absorbing sunlight and the organism and the non-organism suspended matters can scatter light and prevent plants from photosynthesis.

\section{TDS and TSS}

The range value (39800- $40400 \mathrm{mg} / \mathrm{L})$ and the average $(40100 \mathrm{mg} / \mathrm{L})$ of total dissolved solids (TDS) was found to be more than three times above the tolerance limit prescribed by (NE,1999; WHO,2017) and hence it is necessary to be removed by effluent treatment before discharging to safeguard the environment.

The total suspended solids (TSS) of tannery effluent samples were 2100 to $2500 \mathrm{mg} / \mathrm{L}$ with a mean of $2245 \mathrm{mg} / \mathrm{L}$. In fact, these values were higher 22 times than the permissible standard limits for effluent discharge (ISI, 2000). TSS potentially increases the sedimentation in wastewater, changes in soil porosity, and causes depletion of oxygen.

\section{COD and BODs}

The mean COD and BOD 5 of the effluents samples were in the range 4000-5000 mg/L and 2000-3200 mg/L, respectively. The results show that COD and $\mathrm{BOD}_{5}$ values in the tannery effluents were 44 times higher than the maximum allowable limits in discharged effluents (NE,1999). Dissolved oxygen is an index of the total organic content of water oxygen demanding substance in water. It means an amount of oxygen required for oxidation of oxidizable organic matter. The COD is a more realistic parameter this indicates the pollution status of a water body as it is related to all organic matter present (WQM, 1999). On the other hand, $\mathrm{BOD}_{5}$ is directly proportional to the decomposition of dead organic matter and can be correlated with pollution status present in the lake and hence the higher values of $\mathrm{BOD}_{5}$ can be correlated with pollution status (BIS,1983; Mccoy \& Olson,1986; Yurteri \& Gurol,1987). 


\section{Hardness and Alkalinity}

It was observed from Table 2 that the concentration of total hardness, Ca-hardiness, and total alkalinity were extremely high in comparison with the standard levels of discharging in the land (Hasan et al., 2021). The high levels of carbonates influence calcium so that magnesium ions become insoluble mineral, leaving sodium as dominant ions in solution. Increasing alkalinity of effluent can intensify soil conditions and can parallelly destroy the agriculture and can also affect the life cycle of animals and plants dependent on water (Bai et al., 2010; Hasan et al., 2021).

\section{Free Ions}

The average concentration of dissolved metal ions (i.e. $\mathrm{Na}, \mathrm{K}, \mathrm{Mg}, \mathrm{Ca}, \mathrm{Fe}$, and $\mathrm{Mn}$ ions) in the leather tannery effluent exceeded the standard disposal limits (NE,1999; WHO,2017). The metal ions in this study were present in the following order: $\mathrm{Na}>\mathrm{Mg}>\mathrm{Ca}>\mathrm{K}>\mathrm{Fe}>$ Mn.

All the studied negative ions were extremely higher than max allowable limits (ISI,2000; Owusu-Ansah et al.,2015; WHO,2017) and they were in the order: $\mathrm{Cl}^{-}>\mathrm{NO}_{3}{ }^{-}>\mathrm{SO}_{4}^{-2}>$ $\mathrm{NO}_{2}^{-}>\mathrm{F}^{-}$.

The very high concentrations of previous ions imply environmental pollution and may cause human illness and can disturb plant growth.

\section{Conclusion}

To conclude, characterization and determination of tannery effluent indicated a heavy load of pollutants. Tannery leather effluent in freshwater affects the quality of it while discharging effluent to soil can eliminate most of the rhizosphere fungi and can lead to fertility problem. The high levels of studied parameters (ICMR,1975; BIS,1983; Bai et al., 2010) have a negative influence on germination, plant growth, irrigation, and absorption of water and nutrients (ICMR 1975; BIS,2003; Solaimali \& Saravana Kumar, 2004; Misra \& Pandey, 2005; Shakunthala et al., 2010; WHO,2017). Therefore, the effluents from Lawdar tannery industry are not recommended for human activities unless appropriate treatments are selected. 


\section{References}

Akan, J. C., Moses, E. A., Ogugbuaja, V. O., \& Abah, J. (2007). Assessment of tannery industrial effluents from Kano metropolis, Kano State, Nigeria. Journal of Applied Sciences, 7(19), 2788-2793.

APHA (2005), Standard Methods for Examination of Water and Wastewater, (21 Edition), American Public Health Association, Washigton D.C.

Beg, K. R., \& Ali, S. (2008). Chemical contaminants and toxicity of Ganga river sediment from up and down stream area at Kanpur. American Journal of Environmental Sciences, $4(4), 362$.

Bhaduri, M. (2021). Available techniques of wastewater management practices in Indian tanneries: A literature review. Journal of Environmental Treatment Techniques, 9(2), 491498.

BIS (2003). Bureau of Indian Standards, New Delhi IS: 10500:1991 edition- 2.2(20032009).

Hasan, MM., Alam, AKMM., Haque AKMM, et al. (2021). Impacts of textile and leather effluent on environment: an assessment through life cycle of fishes and plants. J Textile Eng Fashion Technol. 7(3),111-117. http://10.15406/jteft.2021.07.00276 .

ICMR (1975). Manual of Standards of Quality for Drinking Water Supplies. Indian Council of Medical Research, Spl. Rep. Ser.No.44.

ISI (2000) Guide for Treatment and Disposal of Effluents of Tanning Industry. Indian Standards Institution, New Delhi, India.

Jeffery, G.H. (1996). Vogel's Text Book of Quantitative Chemical Analysis (5th Ed.) Addison Wesley, Longman Ltd., Harlow, England.

Ling, T. Y., Dana, M. J., Bostam, S., \& Nyanti, L. (2012). Domestic wastewater quality and pollutant loadings from urban housing areas. Iranica Journal of Energy \& Environment, $3(2), 129-133$.

Mccoy, W. F., \& Olson, B. H. (1986). Relationship among turbidity, particle counts and bacteriological quality within water distribution lines. Water Research, 20(8), 1023-1029. 
Misra, V., \& Pandey, S. D. (2005). Hazardous waste, impact on health and environment for development of better waste management strategies in future in India. Environment international, 31(3), 417-431.

NE (1999) National Environment, Standards for Discharge of Effluent into Water or on Land. Regulations, S.I. No 5, Uganda.

NEQS (2000), National Environmental Quality Standards for municipal and liquid industrial effluents. https://epd.punjab.gov.pk/system/files/Revised\%20NEQS\%202000.pdf (Revised) (Accessed 11 Sept, 2021).

Owusu-Ansah, E. D. G. J., Sampson, A., Amponsah, S. K., Abaidoo, R. C., \& Hald, T. (2015). Performance, compliance and reliability of waste stabilization pond: effluent discharge quality and environmental protection agency standards in Ghana. Res. J. Appl. Sci. Eng. Technol., 10(11), 1293-1302.

Raj, E. M., Sankaran, D. P., Sreenath, S. K., Kumaran, S., \& Mohan, N. (1996). Studies on treated effluent characteristics of a few tanneries at Crompet, Madras. Indian J. Environ. Prot, 16, 252-254.

Saha, B., \& Azam, F. A. B. (2021). Probable ways of tannery's solid and liquid waste management in Bangladesh-An overview. Textile \& Leather Review, 4(2), 76-95. https://doi.org/10.31881/TLR.2020.25

Salah AW., Abdel Monem M. Ahmed M., M.S. Adam, and M.A. Mohamed (2013). Adsorption studies on the removal of hexavalent chromium contaminated wastewater using activated carbon and bentonite. Asian Journal of Chemistry; 25(15), 8245-8252. http://dx.doi.org/10.14233/ajchem.2013.13559

Shakunthala, B., Shivanna, S., \& Doddaiah, S. (2010). Urban wastewater characteristic and its management in urban areas - a case study of Mysore City, Karnataka, India. Journal of Water Resource and Protection, 02(08), 717-726.

Solaimali, A. and Saravana Kumar, R. (2004). Irrigation with Poor Quality Water on Soil and Crop in Water Pollution Assessment and Management. Daya Publishing House, New Delhi. pp.407-4239. 
Sponza, D. T. (2021). Treatment of leather industry wastewater with sequential forward osmosis (FO) and reverse osmosis (RO) hibrid prosesses and re-coveries of economical merit materials. J Nanosci Nanomed Nanobio 4: 008.

Subramanyam N.S., and Sambamurty A.V.S.S. Ecology, 2nd Ed. Narosa Publishing House, New Delhi 2006. 635 pages.

Sulieman, A. M. E. H., Yousif, A. W. M., \& Mustafa, A. M. (2010). Chemical, physicochemical and physical properties of wastewater from the Sudanese fermentation industry (SFI). In Fourteenth International Water Technology Conference (Vol. 14, pp. 305$315)$.

Sultana, R., Ahmed, S., \& Zohra, F. T. (2021). Development of adsorbent from sugarcane bagasse for the removal of pollutants from chrome tanning effluents. Textile \& Leather Review, 4(2), 65-75. https://doi.org/10.31881/TLR.2020.24 .

Tadesse, G. L., Guya, T. K., \& Walabu, M. (2017). Impacts of tannery effluent on environments and human health: a review article. Advances in Life Science and Technology, 54, 10.

Tariq, M., Ali, M., \& Shah, Z. J. S. E. (2006). Characteristics of industrial effluents and their possible impacts on quality of underground water. Soil Environ, 25(1), 64-69.

Whitehead, P. G., Mimouni, Z., Butterfield, D., Bussi, G., Hossain, M. A., Peters, R., ... \& Ager, D. (2021). A new multibranch model for metals in river systems: Impacts and control of tannery wastes in Bangladesh. Sustainability, 13(6), 3556. https://doi.org/10.3390/su13063556

WHO (2017), World Health Organization. WHO Guidelines for Drinking-Water Quality, 4th ed.; incorporating the first addendum. Geneva, pp. 1-541.

WQM, Report, 1999. Annual Report on Water quality monitoring of upper and lower lakes Bhopal. Vol. I and II.

WQR (2006), Water Quality Regulations, Licence Application and Renewal as per Legal Notice 120, Kenya Gazette supplement No 68; $29^{\text {th }}$ September, 2006. http://www.fao.org/faolex/results/details/en/c/LEX-FAOC084962/ (Accessed 11 Sept, 2021). 
Academic Journal of Research and Scientific Publishing | Vol 3 | Issue 30

\section{Publication Date: 5-10-2021 ISSN: 2706-6495}

Yurteri, C., \& Gurol, M. D. (1987). Removal of dissolved organic contaminants by ozonation. Environmental progress, 6(4), 240-245.

Copyright (C) 2021 Adel A. M. Saeed, Nasser M. N. Masood, and Ali N. A. Al-Kumi, AJRSP. This is an open-access article distributed under the terms of the Creative Commons Attribution License (CC BY NC).

Doi: doi.org/10.52132/Ajrsp.e.2021.306 